\title{
La 'vista in prima persona' tra esperienza reale e fruizione digitale
}

\author{
Graziano Mario Valenti \\ Alessandro Martinelli
}

Il contributo espone i termini di una riflessione critica sul tema della 'vista in prima persona' così come definita nell'ambito delle rappresentazioni tridimensionali digitali virtuali interattive. II tema gemmato da considerazioni riguardanti la meraviglia percettiva, comunicativa, illusoria e narrativa, propria delle prospettive architettoniche, analizza alcuni scenari della fruizione prospettica digitale, confrontandoli con le caratteristiche fondamentali dell'esperienza naturale del movimento e della visione nel mondo reale. L'obiettivo cui mira la ricerca, oggetto di questo contributo, è di individuare alcune macroscopiche criticità e lacune funzionali, oggi singolarmente trascurate, sulle quali sia possibile intervenire qualitativamente per perfezionare l'esperienza percettiva e, per conseguenza, l'attività conoscitiva dello spazio virtuale digitale così come dell'informazione in esso contenuto.

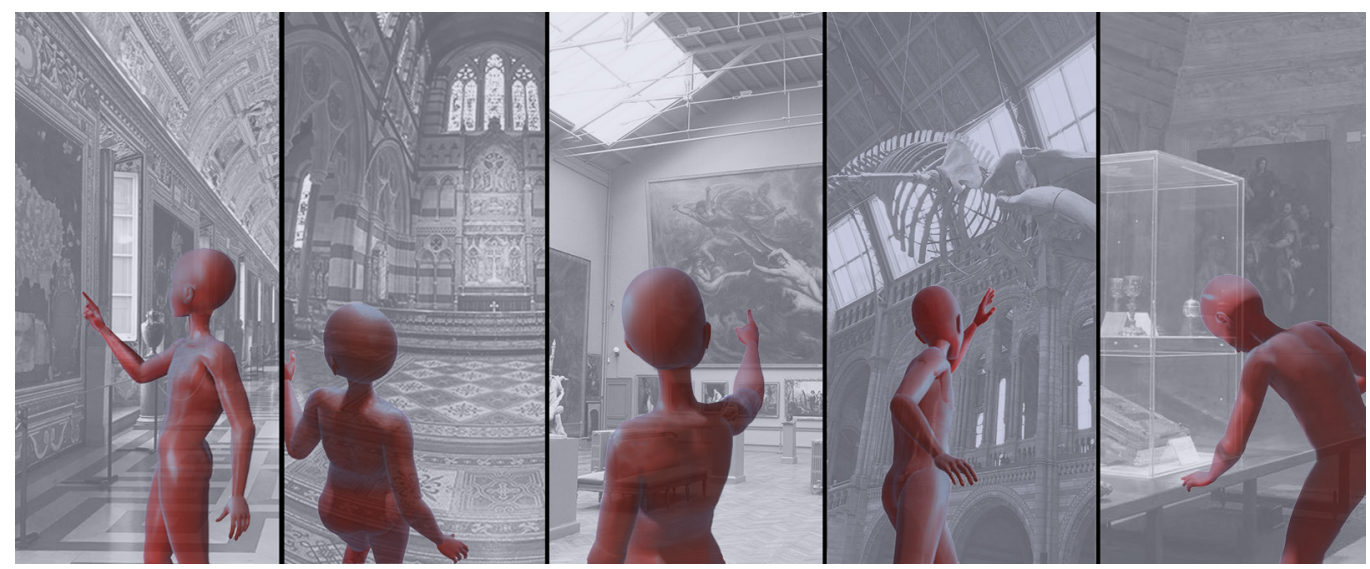




\section{La fruizione digitale dello spazio virtuale}

L'esperienza diretta dello spazio reale è talmente complessa e talvolta persino personale che è opera impervia tentare di generalizzarla. È probabilmente questa la ragione primaria che rende ancora oggi, nonostante la straordinaria evoluzione tecnologica, un'esperienza 'altra', diversa, ogni simulazione digitale che ambisca a riprodurne efficacemente l'impatto sensoriale e il connaturato traguardo conoscitivo. Non meraviglia dunque che le simulazioni di maggior successo, che vedono il fruitore immerso in un mondo virtuale, propongano in realtà mondi irreali [Kullmann 20I4], a tratti fantasiosi se non addirittura 'fumettistici', ove vale l'esperienza di per sé, come la frequentazione di un grande parco giochi, la cui natura non è mai da associare e ancora meno da confrontare con l'esperienza nel mondo reale (es. Fortnite [Pohl 20 I7], Minecraft [Overby 20I5]). (fig. I).

Se da un lato, questo approccio è perfettamente coerente con gli obiettivi e lo sviluppo di un videogioco, appare singolare, oltre che riduttivo, poter contare esclusivamente su questa particolare enfasi narrativa. Fra i casi più evidenti di questa forzatura, possiamo annoverare la fruizione digitale virtuale degli spazi museali. Questa si manifesta in vario modo: dal prodotto ipertestuale, alla sequenza fotografica semplificata dello spazio tridimensionale, per giungere ai prodotti detti di gamification attraversando il terreno di alcune ovvie ma preziose esperienze di rappresentazione digitale tridimensionale (esempi italiani: Museo dei Brettii e del Mare [Barbieri 20 I 6], MUSE, II Parco degli Alberi Parlanti; esempi internazionali: Smithsonian Museum of Natural History, Cleveland Museum of Art, Seattle Art Museum [Ding 20 I 7]). Considerato che gli ipertesi non possono essere annoverati fra le esperienze di realtà virtuale, che i prodotti improntati alla gamification seppur efficaci, utilizzano un diverso canale di comunicazione, un escamotage, per portare il fruitore a fare propria l'esperienza conoscitiva, è venuto spontaneo domandarsi quali fossero le lacune sensoriali che rendono ancora oggi inconfrontabili le due esperienze [Chardonnet 2017; Chattha 2018] e vedere se v'era spazio per fornire un contributo di ricerca utile a colmarle.

Già dalla primissima ricognizione, gli ambiti di approfondimento sono apparsi numerosi, perlopiù affrontabili solo in maniera interdisciplinare, richiedendo che siano messe a sistema competenze di geometria, ottica, informatica, anatomia, neurologia, psicologia, etc. All'interno di questo scenario, la nostra attenzione è quindi stata focalizzata su di un aspetto centrale e prossimo alla nostra ricerca, che, rispetto al ruolo che ricopre, c'è apparso fin troppo trascurato: la fruizione dello spazio tridimensionale nella vista detta 'in prima persona' (fig.02). Su questo aspetto ha preso dunque avvio una prima consistente ricognizione seguita da una riflessione analitica, volta ad individuare criticità e potenzialità: operative, percettive e conoscitive.

\section{La vista in prima persona}

La definizione 'vista in prima persona', lievemente ambigua, assume senso solo nel riconoscimento di ruoli all'interno della scena virtuale [Gorisse 20 I7]: la vista in prima persona riproduce ciò che vede l'avatar - alter ego digitale di chi fruisce l'esperienza virtuale - durante il movimento nello spazio tridimensionale. La rappresentazione dello spazio digitale, quando

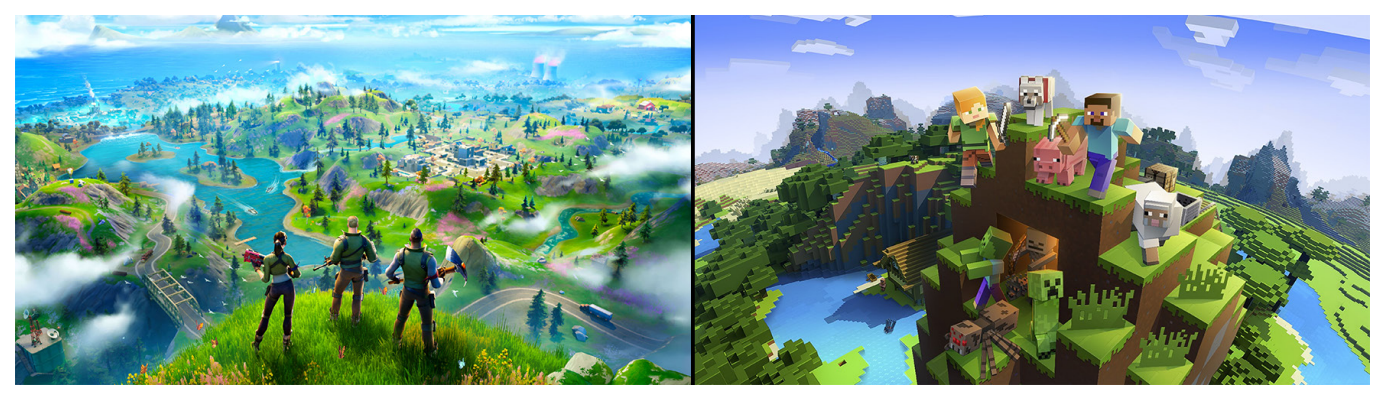


è semplice riproduzione dello spazio reale, si avvale naturalmente della prospettiva: ma che proprietà ha questa prospettiva? $\mathrm{O}$ meglio: quali proprietà non ha questa prospettiva? Ecco: proprio su questa domanda sono nate le prime riflessioni ed è apparso subito evidente come nella pratica comune della implementazione di sistemi di fruizione tridimensionale virtuale, l'attenzione e l'impegno dei creatori è perlopiù sbilanciata verso l'aggregazione di contenuti, mentre a riguardo degli strumenti - nello specifico nella scelta delle modalità di fruizione - si adoperano procedure standard che, fatta eccezione per pochi casi di sperimentazione tecnologica [Berger 20 I8], sono spesso simulazioni molto semplificate del fenomeno reale cui vogliono alludere. Nel corso della nostra ricognizione sullo stato dell'arte,

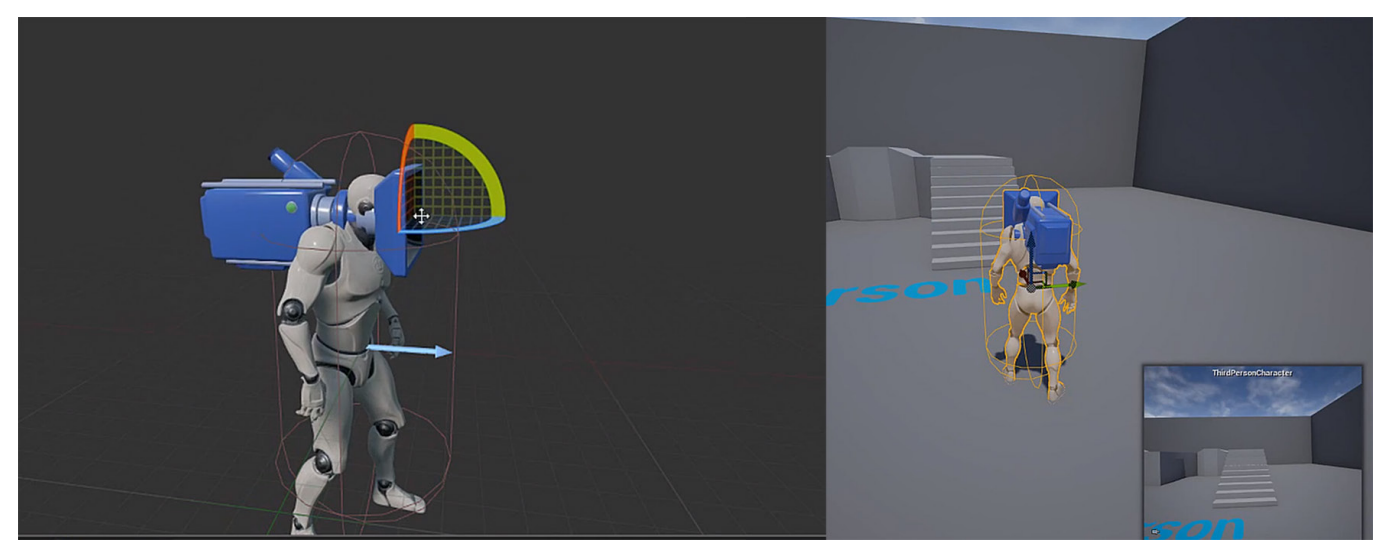

abbiamo identificato cinque ambiti di approfondimento qualitativo, strettamente legati alla vista in prima persona e, per quanto detto, alla prospettiva, che riteniamo debbano avere un'attenzione fondamentale nella progettazione di una esperienza digitale in realtà virtuale. Li decliniamo qui come caratterizzanti la prospettiva, poiché l'ispirazione di questa ricerca è scaturita proprio dall'osservazione del carattere, geometrico-proiettivo, immersivo, percettivo, illusorio e narrativo delle prospettive parietali la cui produzione ha avuto il suo massimo splendore fra il XIV e il XVII secolo e che ancora oggi, oltre a continuare a stupire, possono essere preziosa fonte di indirizzo per individuare soluzioni utili alle simulazioni virtuali future.

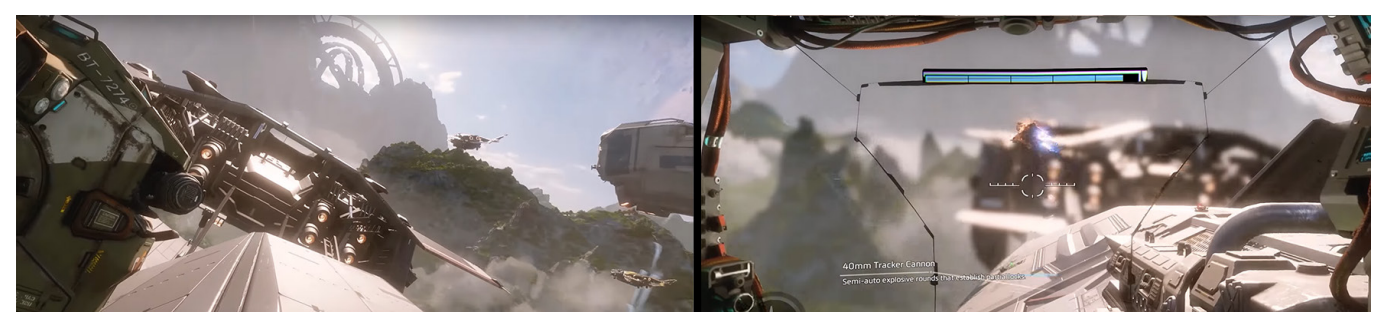

\section{Ambiti qualitativi caratterizzanti l'esperienza tridimensionale virtuale}

L'ordine logico sequenziale nel quale gli ambiti qualitativi sono qui espressi, segue un percorso che va dal dato oggettivo a quello soggettivo, dal certo all'incerto. Gli autori sono tuttavia consapevoli che altre sequenze possono essere individuate parimenti utili e significative, così come gli ambiti selezionati, sono soggettivamente e contestualmente importanti per la ricerca cui sono finalizzati, ma non esaustivi per la completa definizione del problema. 
La qualità geometrica della prospettiva è il fattore più elementare e nello stesso tempo basilare e fortemente caratterizzante la rappresentazione dello spazio percepito dall'osservatore. Lo spazio tridimensionale digitale real-time è rappresentato con le regole della perspectiva artificialis. Diversi sono gli assunti, dati troppo per scontati, che derivano da questa esperienza: anche senza addentrarsi nelle questioni di interpretazione culturale della prospettiva, sollevate da Panofsky e Gioseffi, appare opportuno dedicare maggiore attenzione a come la forma dello spazio sia percepita durante il movimento [Sun Qi 20 I8]. Si allude in particolare alla capacità della mente di normalizzare lo spazio osservato a fronte di piccole oscillazioni del punto di vista. Attenuazioni delle deformazioni proiettive dello spazio, che non sono presenti nell'immagine prospettica dinamica digitale o che il dispositivo utilizzato non le rende pienamente applicabili. Si pensi, ad esempio, quanto sia poco naturale - senza conoscere i principi della prospettiva - percepire dal vivo e nella piccola scala la possibile convergenza in fuga delle linee verticali, conseguente ad una consistente rotazione zenitale della testa verso l'alto o verso il basso, e come questa appare invece evidente in una immagine bidimensionale, proiezione del medesimo spazio. Va inoltre ricordato che la visione umana è binoculare e che ogni semplificazione monoculare è già di per sé una forma immersiva significativamente riduttiva.

La qualità fotografica della prospettiva interessa invece quegli aspetti fisici ed ambientali che concorrono ulteriormente a modificare il rigore geometrico proiettivo. Questi possono facilmente essere individuati riflettendo sui fenomeni dell'immagine che si controllano operando sulla macchina fotografica [Simolyanskiy 2017] come ad esempio: profondità di campo, messa a fuoco, nitidezza, luminosità, contrasto (fig. 3).

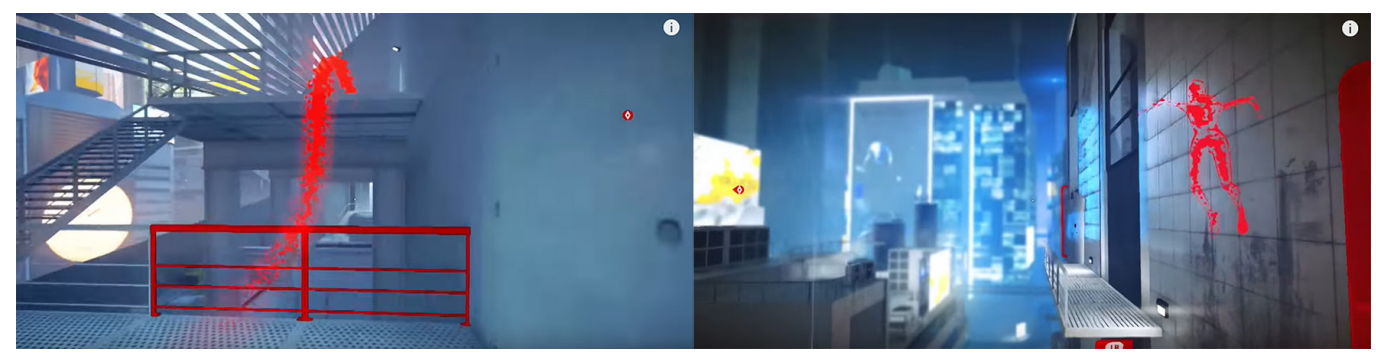

Un ruolo particolare è ricoperto dall'ampiezza del campo visivo, che tende ad essere aumentata più del dovuto per rendere l'idea della spazialità che fra vista periferica e movimenti oculari viene normalmente percepita dall'osservatore. Vi è infine un notevole contrasto fra percezione reale e percezione digitale riguardante l'ibrido fra movimenti naturali e movimenti di macchina caratteristici dell'esperienza cinematografica. Nell'esperienza digitale questi movimenti sono di frequente miscelati senza soluzione di continuità rendendo da un lato l'esperienza forse più ricca ma allo stesso tempo allontanandola dalla realtà. Alludiamo alle panoramiche, le carrellate, le zoomate, ecc. tutti movimenti che non appartengono all'esperienza naturale dello spazio reale. Maggiori elementi a questo proposito saranno forniti all'interno della qualità dinamica della prospettiva.

La qualità scenografica della prospettiva riguarda invece proprio gli elementi costituenti la scena e la loro articolazione nello spazio. Rispetto al cinema, ove l'impostazione della camera è predefinita, e rispetto al teatro ove la posizione dell'osservatore è sostanzialmente nota, in ambito di fruizione indiretta virtuale, l'osservatore si muove in piena libertà potendo esplorare potenzialmente ogni angolo della scena. Nel progetto di una esperienza di fruizione museale virtuale, per esempio, il progetto dell'ambiente non potrà limitarsi alla definizione degli apparati espositivi, utili ad enfatizzare la percezione degli oggetti esposti. Sarà piuttosto necessario dedicare particolare attenzione all'introduzione di accortezze scenografiche a valenza attrattiva che avranno l'obiettivo di indirizzare verso percorsi il fruitore dello spazio virtuale [Nielsen 20l6] (fig. 4). 
La qualità percettiva della prospettiva è di per sé un macro-tema, poiché potrebbero essere considerate in esso tutte le altre qualità esposte. Si vuole invece qui utilizzare questo termine per indicare solo alcuni aspetti che caratterizzano la percezione e che già da soli si configurano come ampissimi campi di ricerca. II primo riguarda la percezione del colore in particolare come attraverso di esso si possa modificare la gerarchia dimensionale dello spazio, indirizzare il percorso e modificarne i tempi di completamento [Salamin 20 I0] (fig. 5). II secondo riguarda invece la percezione delle illusioni prospettiche [Bergström 2016] e come con esse sia possibile sottolineare, svelare e indirizzare la conoscenza (fig. 6).

Si pensi, ad esempio, alla maestria nell'uso della anamorfosi, visibile nell'opera attribuita a Jean François Niceron (16|3-1646), presente nel Convento di Trinità dei Monti a Roma e riguardante San Giovanni Evangelista nell'isola di Pathmos mentre scrive l'Apocalisse. Un'opera ove il fruitore è sollecitato a muoversi da espedienti prospettici per giungere alla conoscenza e fare proprio il messaggio narrato [Trevisan 20I5].

La qualità dinamica della prospettiva, come anticipato in riferimento alla qualità fotografica, riguarda il movimento del centro di proiezione, associato al fruitore dell'ambiente virtuale. Le soluzioni oggi presenti, da un lato utilizzano eccessive semplificazioni, dall'altro tendono ad imitare movimenti di camera che pur familiari, appartengono al repertorio espressivo dell'immagine cinematografica e non sono pertanto caratteristici dell'esperienza visiva personale. Con riferimento al naturale muoversi dell'essere umano che procede camminando nello spazio reale osservando ciò che lo circonda, il corrispondente avatar progettato per lo spazio virtuale, dovrebbe avere una coppia di punti di vista - centri di proiezione della prospettiva - posti in corrispondenza degli occhi, che siano soggetti nell'orientamento rispettivamente al movimento degli occhi, all'orientamento della testa e infine alla postura del corpo che la testa sostiene. Analizziamo ad uno ad uno questo movimenti e vediamo come siano integrati negli attuali sistemi di rappresentazione.

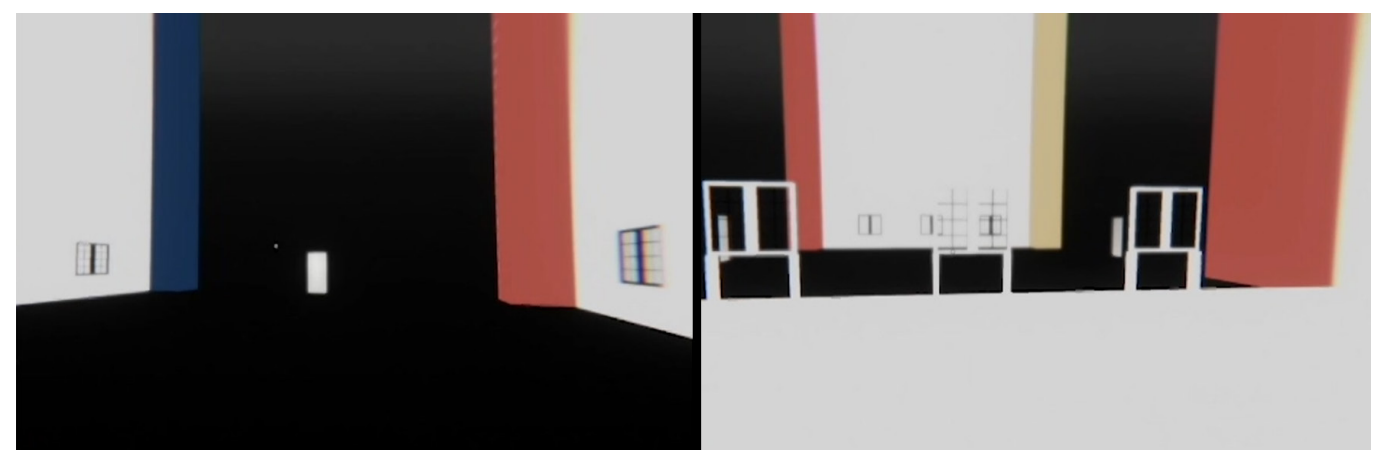

\section{Aspetti motori della vista in prima persona}

Gli occhi si orientano nello spazio attraverso movimenti di vario genere, sia volontari che involontari, alcuni quasi impercettibili e poco influenti sulla rappresentazione, altri viceversa più consistenti e non trascurabili sul piano percettivo. Nell'ambito dei movimenti involontari vanno sicuramente annoverati, i riflessi vestibolo-oculare e optocinetico, entrambi utili a mantenere il punto collimato compensando eventuali movimenti della testa e del corpo. Appartengono invece ai movimenti volontari, quelli detti di vergenza, che permettono ai due occhi la collimazione di un singolo punto, anche se in allontanamento (divergenza) e avvicinamento (convergenza) al nostro viso. Per le nostre valutazioni ricopre un ruolo di fondamentale importanza, il movimento volontario saccadico che ha l'obiettivo di far ruotare il bulbo oculare portando a collimare gli oggetti osservati con la regione centrale della retina, di massima acutezza visiva. Questo movimento che consentirebbe un'escursione di circa 90 gradi, in realtà è utilizzato di norma entro i 20 gradi - per esempio circa due gradi quanto si percorrono le righe di un testo - oltre i quali si tende istintivamente a mettere in 
gioco la rotazione della testa. Su un piano percettivo, come ci insegna l'orbitazione oculare nella veduta vincolata, le modifiche al prodotto proiettivo, anche considerando la visione binoculare - sono minime ed è pertanto difficile percepire differenze proiettive tra il movimento saccadico svolto a fronte di uno spazio reale rispetto al medesimo conseguito a fronte di una proiezione - su schermolvisore bidimensionale dello stesso spazio.

I movimenti della testa, in ambito digitale, sono tradotti generalmente come rotazione della direzione principale della vista prospettica, applicata proprio in corrispondenza del centro di proiezione. Questo elimina completamente il fenomeno della parallasse che invece si

Fig. 6. Superliminal (2019): le alterazioni prospettiche guidano il fruitore lungo il percorso.

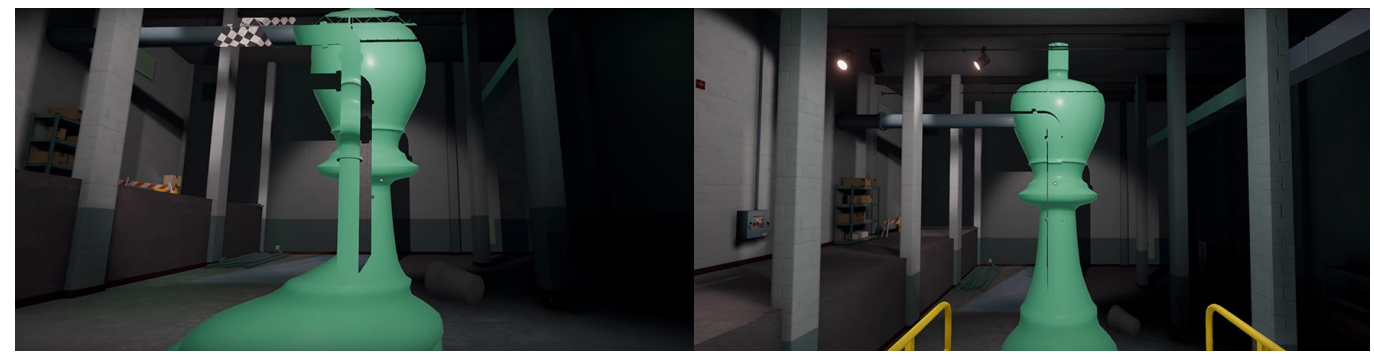

percepisce nella rotazione naturale, essendo per noi impossibile ruotare la nostra testa mantenendo fermo ciò che percepiamo essere il nostro centro di proiezione. Va inoltre detto che i movimenti in ambito digitale sono per lo più lineari, come lo sono le panoramiche, ma nella realtà, quando muoviamo la testa, il movimento saccadico si prende le sue libertà: si sofferma e accelera secondo esigenza, trasformando la percezione dello spazio in un'esperienza decisamente diversa rispetto a quella cui siamo abituati in ambito digitale. I movimenti del corpo, infine, offrono ulteriore spunto di riflessione, proseguendo nell'analisi

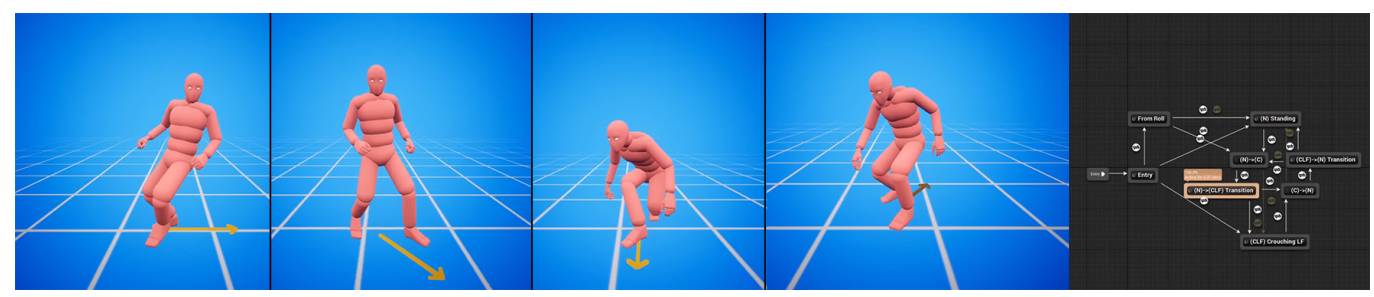

delle singolarità applicative fra digitale e virtuale. Nel corso del tempo, dalle origini della fruizione tridimensionale digitale fino ad oggi, notevoli sono stati i perfezionamenti nella simulazione delle posture che descrivono i movimenti dell'avatar in ambito virtuale. Se in origine il movimento era tradotto come semplice traslazione dal punto di origine a quello di destinazione, oggi - nei modelli più raffinati - è invece il prodotto di una complessa sequenza cinematica, caratteristica di un insiemi di organi di movimento in cui è discretizzato il corpo dell'avatar e che concorrono a riposizionare i relativi - visione binoculare - centri di vista posti in corrispondenza degli occhi (fig 7).

Sequenze cinematiche che sono prodotte attraverso la normalizzazione di dati acquisiti mediante tecniche di motion capture o, più recentemente, di riconoscimento automatico a mezzo di procedure di Machine Learning per tecniche come Face Swapping [Nirkin 2019] o Physic Character Control [Bergamin 2019]. Se da un lato il panorama delle applicazioni di Realtà Virtuale, rendono disponibili vasti database di motion-capture dedicate alle più estreme ed impegnative attività fisiche attribuibili all'avatar (sport, combattimenti, ballo etc.), molta meno attenzione è rivolta ad esplicare pienamente i movimenti più lenti e riflessivi caratteri- 
stici della normalità: solo il cinema di animazione, per meglio caratterizzare i suoi personaggi con espressioni ed emozioni, gli dedica maggiore attenzione. Non vi sono studi specifici, per esempio, che analizzano la postura delle persone durante la visita di uno spazio espositivo. L'attenzione delle ricerche, in questo ambito, è infatti prevalentemente concentrata su percorsi, tempi di permanenza di fronte alle opere, particolari osservati. Paradossale risultato di questa lacuna è che l'avatar digitale che viene generalmente utilizzato nelle simulazioni tridimensionali volte a esperire uno spazio museale, sa correre, saltare, arrampicarsi e ahimè sparare (fig. 8), ma difficilmente sa chinarsi per guardare un'opera dal basso o ruotare il busto per abbassare la testa e percepirne meglio un dettaglio.

Fig. 8. Death Stranding (2019), attualmente la simulazione più fedele delle dinamiche anatomiche e motorie: oltre al carico, vengono considerati anche forma e materiale del terreno, nonché gli aspetti

fisiologici del personaggio stesso.

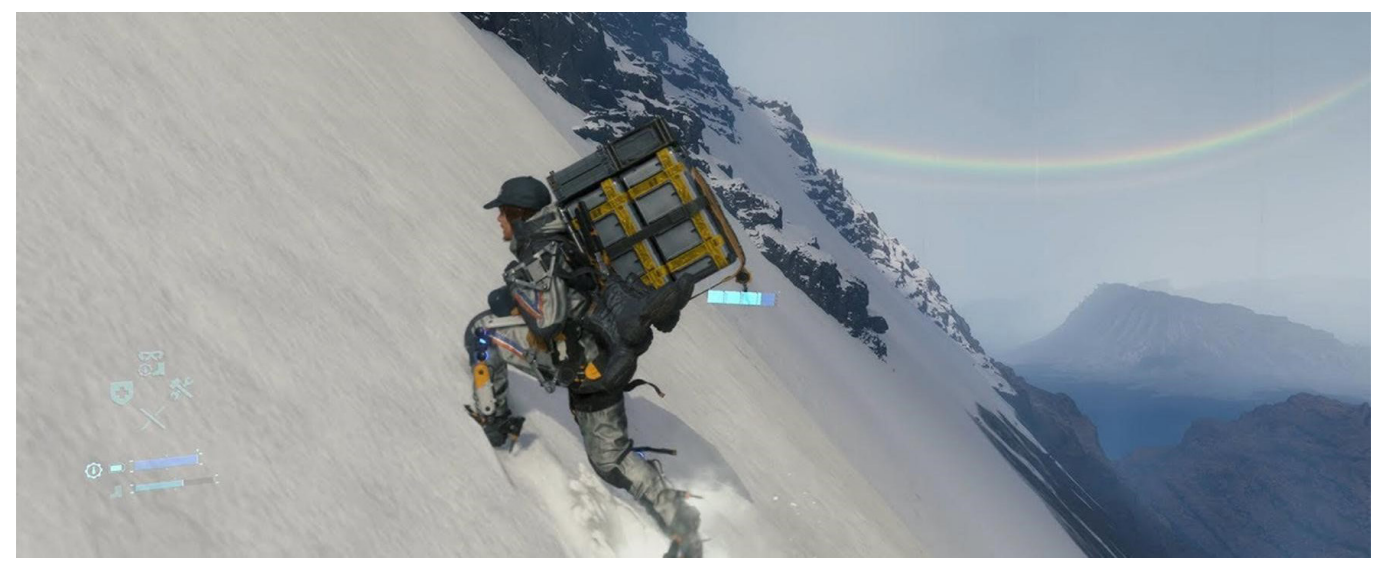

\section{Conclusioni}

Ognuno degli ambiti qui introdotti, dà un'idea della complessità che sottende alla fruizione tridimensionale virtuale e come questa sia affrontata oggi enfatizzandone alcuni aspetti, poiché è paradossalmente più complesso riprodurli nella loro semplice naturalezza. Le applicazioni e i dispositivi tecnologici oggi a disposizione per detta fruizione, sono perlopiù viziati nell'impostazione dall'industria di sviluppo di provenienza e dal relativo mercato di destinazione. La loro applicazione acritica, alimentata dalla universalità strumentale che spesso sembra connaturata negli strumenti digitali, è un rischio sempre presente, dal quale è necessario affrancarsi. Senza dubbio l'esperire i saperi per mezzo di attività di ispirazione ludica a forte impatto emotivo, può essere molto più comunicativo e persuasivo di una lettura di un testo, ma il fenomeno della conoscenza non avviene solo osservando 'fuochi di artificio', scaturisce anche e soprattutto, dalla lenta riflessione durante un'osservazione immobile di un dettaglio particolare. Nella consapevolezza di questa antitesi si muove la nostra ricerca con l'obiettivo di fornire un contributo prima in termine di riflessione critica e poi in termini di metodologia operativa e applicativa, alla fruizione virtuale dello spazio tridimensionale finalizzata ad obiettivi di divulgazione e disseminazione scientifica.

\section{Riferimenti bibliografici}

Barbieri Loris, Bruno Fabio, Mollo Fabio et al. (20 I7). User-centred Design of a Virtual Museum System: a case study. In Advances on Mechanics, Design Engineering and Manufacturing. Proceedings of the International Joint Conference on Mechanics, Design Engineering \& Advanced Manufacturing (JCM 2016), I4-16 September, 2016, Catania, Italy. Springer: International Publishing pp. $156-166$

Beil Benjamin (2010). First Person Perspectives: Point of View und figurenzentrierte Erzählformen im Film und im Computerspiel. Münster: Medien'welten LIT.

Bergamin Kevin, Clavet Simon, Holden Daniel, Forbes James Richard (2019). DReCon: data-driven responsive control of physics-based characters. In ACM Trans. Graph, 38, 6, Art. 206, pp. I- II. 
Berger Laurenz, Wolf Katrin (2018). WIM: Fast Locomotion in Virtual Reality with Spatial Orientation Gain \& without Motion Sickness. In MUM 2018. Proceedings of the 17th International Conference on Mobile and Ubiquitous Multimedia, (MUM 20 18). Association for Computing Machinery, November 2018 , New York, NY, USA, pp. 19-24.

Bergström Ilias, Kilteni Konstantina, SlaterMel (20 I6). First-Person Perspective Virtual Body Posture Influences Stress: A Virtual Reality Body Ownership Study. In PloS one, II, 2, 2016, pp. I-2I.

Chardonnet Jean-Rémy, Mirzaei Mohammad Ali, Mérienne Frédéric (2017). Features of the Postural Sway Signal as Indicators to Estimate and Predict Visually Induced Motion Sickness in Virtual Reality. In International Journal of Human-Computer Interaction, 33: 10, 2017, pp. 77|-785

Chattha Umer Asghar, Shah Munam Ali (2018). Survey on Causes of Motion Sickness in Virtual Reality. In 24th International Conference on Automation and Computing (ICAC). Newcastle upon Tyne, United Kingdom. Newcastel: University press, pp. I-5.

Ding Mandy (2017). Augmented Reality in Museums. In Arts Management \& Technology Laboratory. Arts Management \& Technology Laboratory della Carnegie Mellon University, Heinz College pp. I - 12.

Gorisse Geoffrey, Christmann Olivier, Amato Etienne Armand et al. (2017). First- and Third-Person Perspectives in Immersive Virtual Environments: Presence and Performance Analysis of Embodied Users. In Frontiers in Robotics and Al, 4, p. 33.

Kullmann Karl (2014). Hyper-realism and loose-reality: the limitations of digital realism and alternative principles in landscape design visualization. In Journal of Landscape Architecture, 9:3, pp. 20-31.

Nielsen Lasse T., Møller Matias B., Hartmeyer Sune D. et al. (2016). Missing the point: an exploration of how to guide users' attention during cinematic virtual reality. In Proceedings of the 22nd ACM Conference on Virtual Reality Software and Technology (VRST 'I 6). New York: Association for Computing Machinery, pp. 229-232.

Nirkin Yuval, Keller Yosi, HassnerTal (2019). FSGAN: Subject Agnostic Face Swapping and Reenactment. In The IEEE International Conference on Computer Vision (ICCV), 29 Oct.-0I Nov. 20 19, Seoul, Korea, pp. 7I84-7I93.

Overby Alexandra, Jones Brian L. (20I5). Virtual LEGOs: Incorporating Minecraft into the Art Education Curriculum. In Art Education, 68: I, pp. $21-27$.

Pohl Brian J., Harris Andrew, Balog Michael et al. (2017). Fortnite: Supercharging 3D Animation Pipelines with Game Engine Technologies. In Digi Pro, 7, 2017, pp. I-4.

Sun Qi, Patnev Anjul, Wei Li-Yi, Saphira Omer et al. (2018). Towards Virtual Reality Infinite Walking: Dynamic Saccadic Redirection. In ACM Trans. Graph., 37, 4, 67, pp. I - 3.

Simolyanskiy Nikolai, Gonzales-Franco Mar (20 I7). Stereoscopic First Person View System for Drone Navigation. In Frontiers in Robotics and Al, 4, pp. I-I I.

Salamin Patrick, Tadi Tej, Blanke Olaf,Vexo Frederic, Thalmann Daniel (20I0). Quantifying Effects of Exposure to the Third and First-Person Perspectives in Virtual-Reality-Based Training. In IEEE Transactions on Learning Technologies, vol. 3, n. 3, pp. $272-276$.

Tevisan Elena (20 I5). II san Giovanni Evangelista di Jean François Niceron: la scoperta di un'apocalisse dell'Ottica. In Graziano Mario Valenti. Prospettive Architettoniche, pp. 365-374. Roma: Sapienza Edizioni.

\section{Autori}

Graziano Mario Valenti, Sapienza Università di Roma, grazianomario.valenti@uniroma l.it Alessandro Martinelli, Sapienza Università di Roma, alessandro.martinelli@uniroma l.it

Per citare questo capitolo:Valenti Mario Graziano, Martinelli Alessandro (2020). La 'vista in prima persona' tra esperienza reale e fruizione digitale/ The 'first-person view' between real experience and digital use. In Arena A., Arena M., Brandolino R.G., Colistra D., Ginex G., Mediati D., Nucifora S., Raffa P. (a cura di). Connettere. Un disegno per annodare e tessere. Atti del $42^{\circ}$ Convegno Internazionale dei Docenti delle Discipline della Rappresentazione/Connecting. Drawing for weaving relationships. Proceedings of the 42th International Conference of Representation Disciplines Teachers. Milano: FrancoAngeli, PP. $3811-3826$. 


\title{
The 'First-Person View' between Real Experience and Digital Use
}

\author{
Graziano Mario Valenti \\ Alessandro Martinelli
}

\section{Abstract}

The contribution exposes the terms of a critical reflection on the theme of "first person view" as defined in the context of interactive virtual digital three-dimensional representations. The theme, gemmed by considerations regarding the perceptive, communicative, illusory and narrative wonder, typical of architectural perspectives, analyzes some scenarios of digital perspective use, comparing them with the fundamental characteristics of the natural experience of movement and vision in the real world. The aim of the research object of this contribution is to identify some macroscopic criticalities and functional gaps, today individually overlooked, on which it is possible to intervene qualitatively to perfect the perceptual experience and, consequently, the cognitive activity of the digital virtual space, as well as the information it contains.

Keywords

first-person view, perspective, perception, realtime 3D, virtual museum.

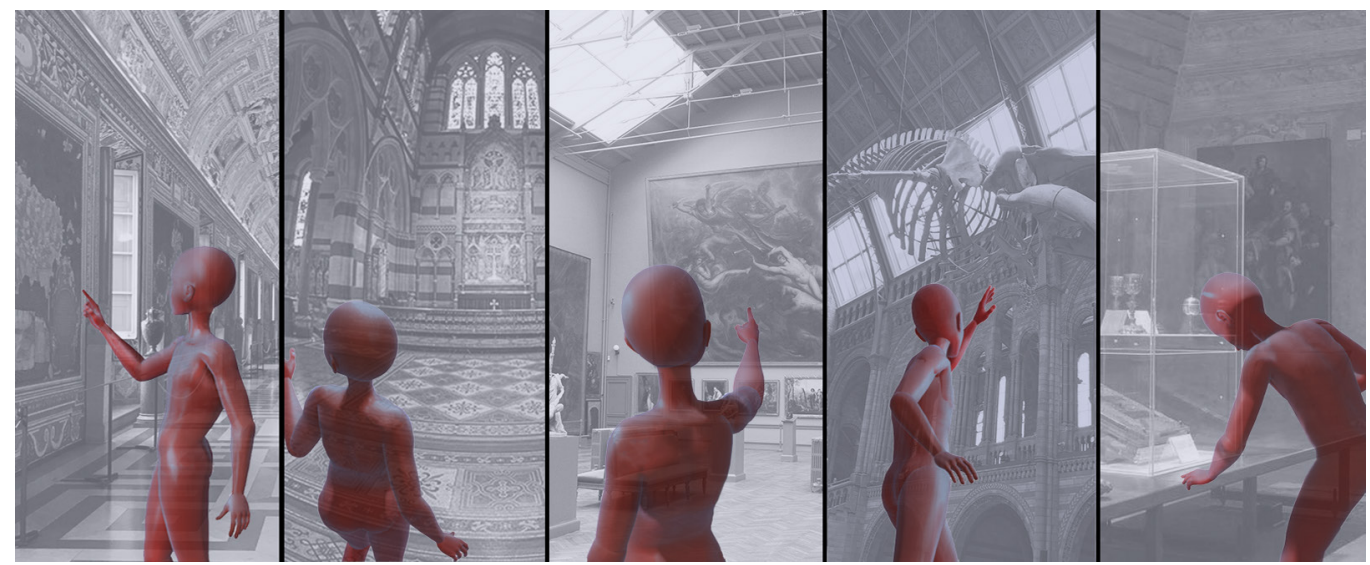




\section{The digital use of the virtual space}

The direct experience of real space is so complex and sometimes even personal that it is impervious to attempt to generalize it. This is probably the primary reason that makes today, despite the extraordinary technological evolution, an 'other' experience, different, any digital simulation that aims to effectively reproduce its sensorial impact and its innate cognitive goal. It is therefore no wonder that the most successful simulations, which see the user immersed in a virtual world, actually offer unreal worlds [Kullmann 20I4], at times imaginative if not even 'comic', where the experience itself is worth, as the attendance of a large playground, the nature of which is never to be associated and even less to compare with experience in the real world (eg Fortnite [Pohl 20 I7], Minecraft [Overby 20I5]) (fig. I).

If on the one hand, this approach is perfectly consistent with the objectives and development of a video game, it seems singular, as well as reductive, to be able to rely exclusively on this particular narrative emphasis. Among the most evident cases of this forcing, we can count the virtual digital use of museum spaces. This manifests itself in various ways: from the hypertext product, to the simplified photographic sequence of the three-dimensional space, to reach the so-called 'gamification' products by crossing the terrain of some obvious but precious experiences of three-dimensional digital representation (italian examples: Museo dei Brettii e del Mare [Barbieri 20 I6], MUSE, The Talking Tree Park; international examples: Smithsonian Museum of Natural History, Cleveland Museum of Art, Seattle Art Museum [Ding 20 17]). Considering that hypertexts cannot be counted among virtual reality experiences, that products based on 'gamification', albeit effective, use a different communication channel, an escamotage, to bring the user to make the cognitive experience their own, it came spontaneously to ask what were the sensory gaps that still make the two experiences unmatched today [Chardonnet 20 I7; Chattha 2018] and see if there was room to provide a useful research contribution to fill them.

Already from the very first survey, the areas of study appeared numerous, mostly treatable only in an interdisciplinary way, requiring that skills of geometry, optics, computer science, anatomy, neurology, psychology, etc. be put into the system. Within this scenario, our attention was therefore focused on a central aspect that is close to our research, which, compared to the role it plays, appeared to be far too neglected: the use of three-dimensional space in the view called 'first person' (fig. 2). On this aspect, therefore, a first substantial recognition began, followed by an analytical reflection, aimed at identifying critical and potential: operational, perceptive and cognitive.

\section{The first-person view}

The slightly ambiguous definition 'first-person view' only makes sense in recognizing roles within the virtual scene [Gorisse 2017]: first-person view reproduces what the avatar sees - the digital alter ego of those who enjoy the virtual experience - during movement in three-dimensional space. The representation of digital space, when it is a simple reproduction of real space, naturally takes advantage of perspective: but what properties

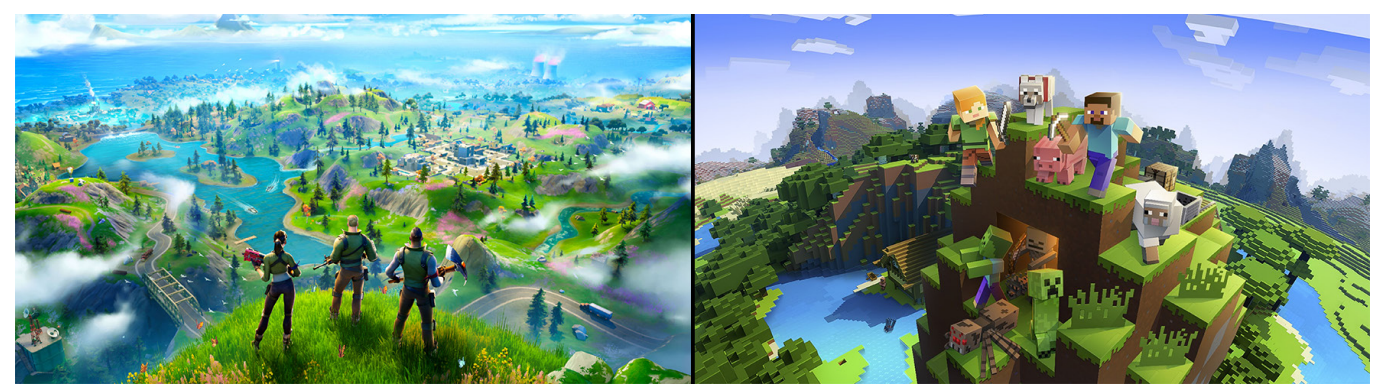


does this perspective have? Or rather: what properties does this perspective not have? Here: the first reflections were born on this question and it became immediately evident how in the common practice of the implementation of virtual three-dimensional fruition systems, the attention and commitment of the creators is mostly unbalanced towards the aggregation of contents, while with regard to the tools - specifically in the choice of the methods of use - standard procedures are used which, with the exception of a few cases of technological experimentation [Berger 20 I8], are often very simplified simulations of the real phenomenon they want to allude to. During our survey on the state of the art, we identified five areas of qualitative analysis, closely related to first-person view and, for

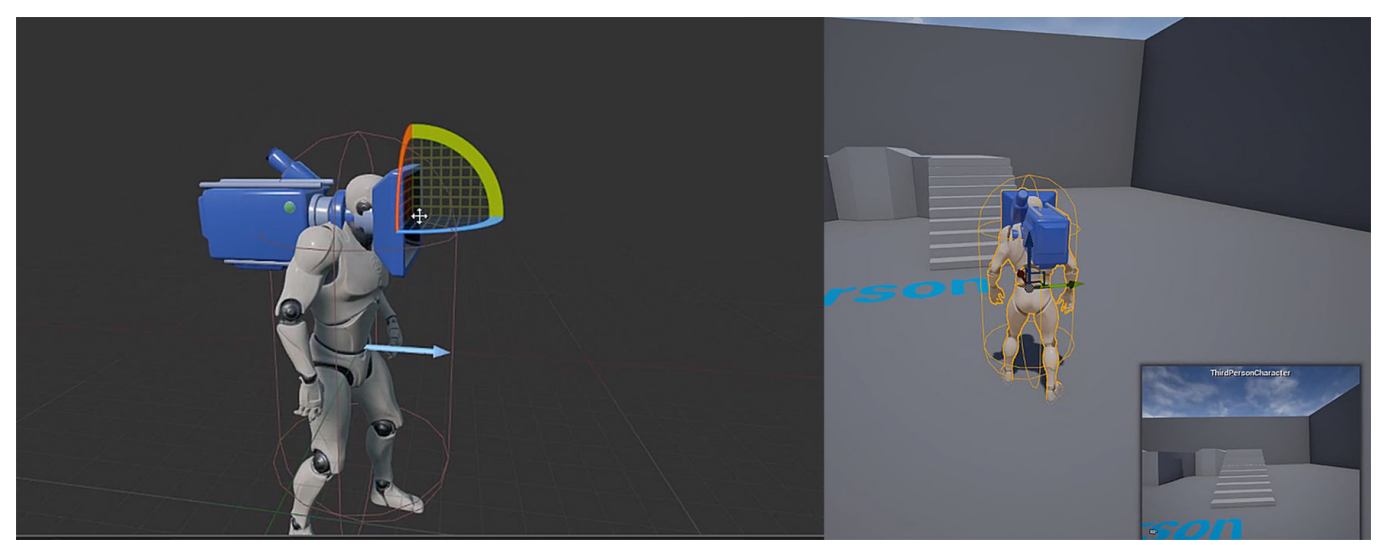

what has been said, to perspective, which we believe must have fundamental attention in the design of a digital experience in virtual reality. We declare them here as characterizing the perspective, since the inspiration of this research came from the observation of the geometric, projective, immersive, perceptive, illusory and narrative character of the wall perspectives, whose production had its maximum splendor among the XIV and XVII century and that still today, besides continuing to amaze, can be a precious source of direction for identifying useful solutions for future virtual simulations.

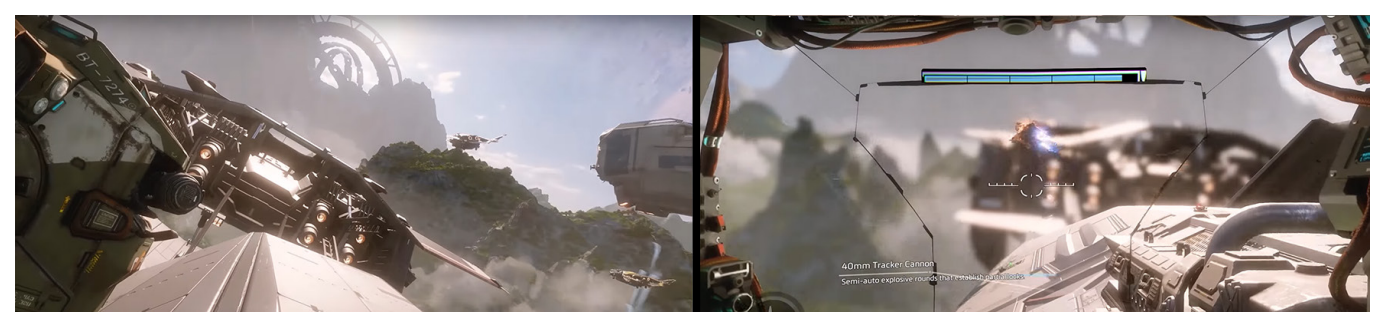

\section{Qualitative areas characterizing the virtual three-dimensional experience}

The sequential logical order in which the qualitative areas are expressed here, follows a path that goes from objective to subjective, from certain to uncertain. However, the authors are aware that other sequences can be identified equally useful and meaningful, as well as the selected areas, are subjectively and contextually important for the research they are aimed at, but not exhaustive for the complete definition of the problem. The 
geometric quality of perspective is the most elementary factor and at the same time basic and strongly characterizing the representation of the space perceived by the observer. The real-time digital three-dimensional space is represented by the rules of perspectiva artificialis. There are several assumptions, taken too much for granted, that derive from this experience: even without going into the questions of cultural interpretation of perspective, raised by Panofsky and Gioseffi, it seems appropriate to dedicate more attention to how the shape of space is perceived during movement [ Sun Qi 2018]. It alludes in particular to the ability of the mind to normalize the space observed in the face of small oscillations of the point of view. Attenuations of the projective deformations of space, which are not present in the dynamic digital perspective image or that the device used does not make them fully applicable. Think, for example, how unnatural it is - without knowing the principles of perspective - to perceive live and in the small scale the possible flight convergence of the vertical lines, consequent to a consistent zenith rotation of the head upwards or downwards, and how this appears instead evident in a two-dimensional image, projection of the same space. It should also be remembered that human vision is binocular and that each monocular simplification is itself a significantly reductive immersive form.

The photographic quality of the perspective, on the other hand, affects those physical and environmental aspects that further contribute to changing the projective geometric rigor. These can be easily identified by reflecting on the phenomena of the image that are controlled by operating on the camera [Simolyanskiy 2017] such as: depth of field, focus, sharpness, brightness, contrast (fig. 3).

Fig. 4. Mirror's Edge (2008):

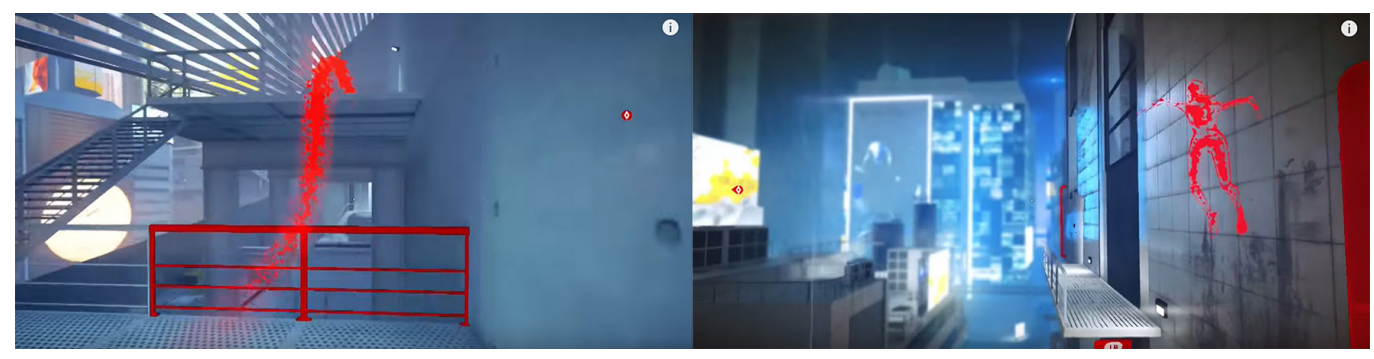

A particular role is played by the amplitude of the visual field, which tends to be increased more than necessary to convey the idea of spatiality that between peripheral vision and eye movements is normally perceived by the observer. Finally, there is a considerable contrast between real perception and digital perception regarding the hybrid between natural movements and machine movements characteristic of the cinematographic experience. In the digital experience, these movements are frequently mixed seamlessly, making the experience perhaps richer on the one hand, but at the same time, moving it away from reality. We allude to the panoramas, the tracking shots, the zooms, etc ... all movements that do not belong to the natural experience of real space. More elements in this regard will be provided within the dynamic quality of the perspective.

The scenographic quality of the perspective, on the other hand, concerns the elements making up the scene and their articulation in space. Compared to the cinema, where the setting of the room is predefined, and compared to the theater where the position of the observer is substantially known, in the context of virtual indirect use, the observer moves freely, potentially exploring every corner of the scene. In the project of a virtual museum fruition experience, for example, the design of the environment cannot be limited to the definition of the display systems, useful to emphasize the perception of the exhibits. It will rather be necessary to devote particular attention to the introduction of scenographic foresight with an attractive value that will aim to direct the user of the virtual space towards paths [Nielsen 20I6] (fig. 4). 
The perceptual quality of perspective is a macro-theme itself, since all the other qualities exposed could be considered in it. Instead, we want to use this term to indicate only some aspects that characterize perception and that already configure themselves as very large fields of research. The first relates to the perception of color in particular how it can change the dimensional hierarchy of space, direct the path and modify its completion times [Salamin 20 I0] (fig. 5).

The second concerns the perception of perspective illusions [Bergström 2016] and how it is possible to underline, reveal and direct knowledge with them (fig. 6).

Think, for example, of the mastery in the use of anamorphosis, visible in the work attributed to Jean François Niceron (1613-1646), present in the Convent of Trinità dei Monti in Rome and concerning San Giovanni Evangelista on the island of Pathmos while writing the Apocalypse. A work where the user is urged to move from prospective expedients to reach knowledge and make the narrated message their own. [Trevisan 20I5]

The dynamic quality of perspective, as anticipated with reference to photographic quality, concerns the movement of the projection center associated with the user of the virtual environment. The solutions present today, on the one hand use excessive simplifications, on the other they tend to imitate camera movements which, although familiar, belong to the expressive repertoire of the cinematographic image and are therefore not characteristic of personal visual experience. With reference to the natural movement of the human being who proceeds walking in real space observing his surroundings, the corresponding avatar designed for virtual space should have a couple of points of view - perspective projection centers - placed in correspondence with the eyes, which are subject in the orientation respectively to the movement of the eyes, to the orientation of the head and finally to the posture of the body that the head supports. Let's analyze one by one this movements and see how they are integrated in the current systems of representation.

Fig. 5. Superliminal (20/9): alterations in the perception

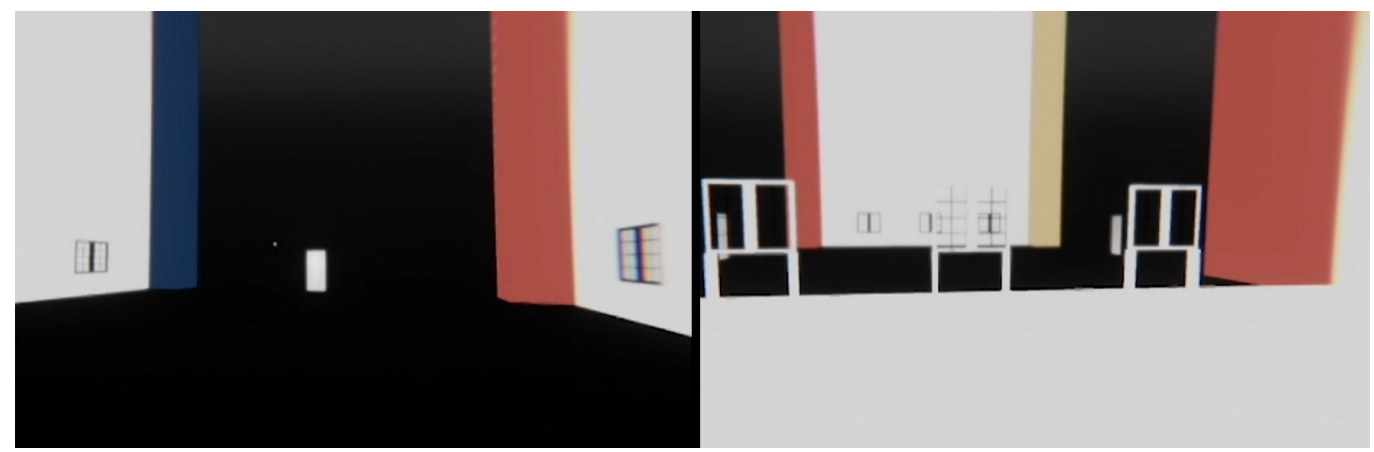

\section{Motor aspects of first-person view}

The eyes are oriented in space through movements of various kinds, both voluntary and involuntary, some almost imperceptible and not very influential on the representation, others vice versa more substantial and not negligible on the perceptual level. In the context of involuntary movements, the vestibular-ocular and optokinetic reflexes must certainly be included, both useful for maintaining the collimated point by compensating for any head and body movements. Instead they belong to voluntary movements, those called vergence, which allow the two eyes to collimate a single point, even if moving away (divergence) and approaching (convergence) to our face. For our evaluations, the voluntary saccadic movement that has the aim of rotating the eyeball leading to collimating the objects observed with the central region of the retina, of maximum visual acuity, plays a fundamental role. This movement, which would allow an excursion of about 90 degrees, is actually normally used within 20 degrees - for example about two degrees when crossing lines of text -, beyond which there is an instinctive tendency to bring the rotation 
of the head into play. On a perceptual level, as the eye orbit teaches us in the constrained view, the changes to the projective product, even considering the binocular vision, are minimal - and it is therefore difficult to perceive projective differences between the saccadic movement performed in front of a real space compared to the same achieved in front of a projection - on a two-dimensional screen / viewer of the same space. The movements of the head, in the digital field, are generally translated as rotation of the main direction of the perspective view, applied precisely at the projection center. This completely eliminates the phenomenon of parallax which is perceived in natural rotation, since

Fig. 6. Superliminal (2019): the perspective alterations guide the user along the way.

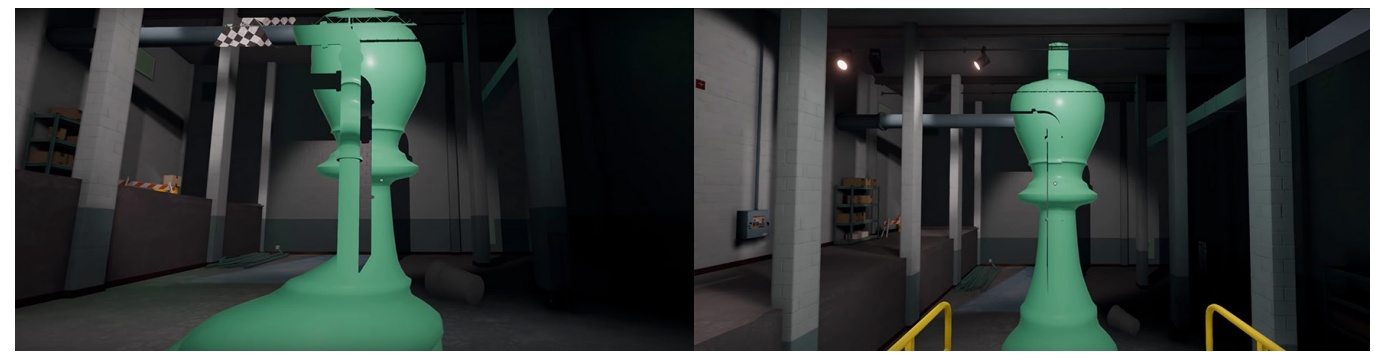

it is impossible for us to rotate our head while keeping still what we perceive to be our center of projection. It must also be said that the movements in the digital environment are mostly linear, as are the panoramas, but in reality, when we move the head, the saccadic movement takes its liberties: it stops and accelerates according to need, transforming the perception of the space in a definitely different experience compared to what we are used to in the digital field.

Finally, the movements of the body offer a further point of reflection, continuing to analy-

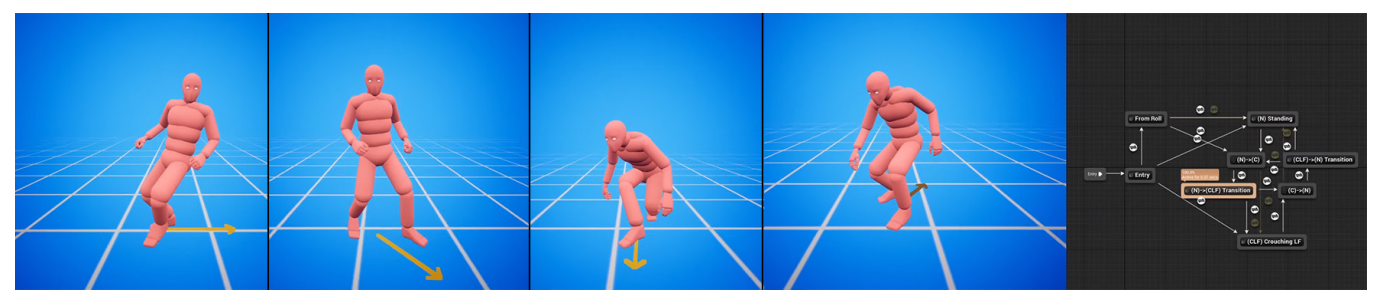

ze the applicative singularities between digital and virtual. Over time, from the origins of three-dimensional digital use to date, there have been significant improvements in the simulation of postures that describe the avatar's movements in a virtual environment. If originally the movement was expressed as a simple translation from the point of origin to the destination, today - in the most refined models - it is instead the product of a complex kinematic sequence, characteristic of a set of moving organs in which the body is discretized of the avatar and which contribute to repositioning the relative - binocular vision - centers of sight placed in correspondence of the eyes (fig. 7). Kinematic sequences that are produced through the normalization of data acquired through motion capture techniques or, more recently, automatic recognition by means of Machine Learning procedures for techniques such as Face Swapping [Nirkin 20 19] or Physic Character Control [Bergamin 2019]. If on the one hand the panorama of Virtual Reality applications make vast motion-capture databases available dedicated to the most extreme and demanding physical activities attributable to the avatar (sports, fighting, dancing, etc.), much less attention is paid to fully explain the slower and more reflective movements characteristic of 
normality: only animation cinema, to better characterize its characters with expressions and emotions, devotes more attention to it. There are no specific studies, for example, which analyze people's posture when visiting an exhibition space. The attention of the researches, in this area, is in fact mainly concentrated on routes, times of permanence in front of the works, particular observed. Paradoxical result of this gap is that the digital avatar that is generally used in three-dimensional simulations aimed at experiencing a museum space, knows how to run, jump, climb and alas shoot (fig. 08), but hardly knows how to bend down to watch a work from low or rotate your torso to lower your head and better perceive a detail.

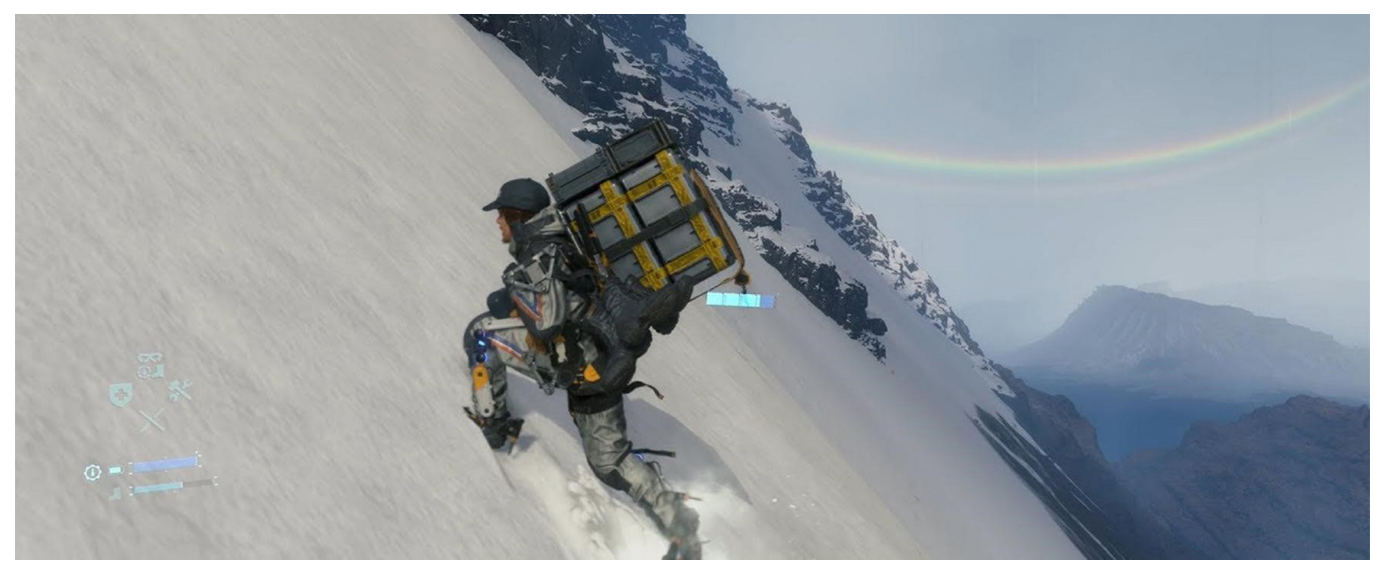

\section{Conclusions}

Each of the areas introduced here gives an idea of the complexity that underlies the virtual three-dimensional use and how this is dealed today by emphasizing some aspects, since it is paradoxically more complex to reproduce them in their simple naturalness. The applications and technological devices available today for said use are mostly spoiled in the setting by the development industry of origin and the relevant target market. Their uncritical application, fueled by the instrumental universality that often seems inherent in digital instruments, is an ever-present risk, from which it is necessary to free oneself. Without a doubt the experience of knowledge by means of activities of playful inspiration with a strong emotional impact, can be much more communicative and persuasive than a reading of a text, but the phenomenon of knowledge does not occur only by observing 'fireworks', it also springs and above all, by the slow reflection during a motionless observation of a particular detail. In the awareness of this antithesis, our research moves with the aim of providing a contribution first in terms of critical reflection and then in terms of operational and application methodology, to the virtual use of the three-dimensional space aimed at the objectives of disclosure and scientific dissemination.

\section{References}

Barbieri Loris, Bruno Fabio, Mollo Fabio et al. (2017). User-centred Design of a Virtual Museum System: a case study. In Advances on Mechanics, Design Engineering and Manufacturing. Proceedings of the International Joint Conference on Mechanics, Design Engineering \& Advanced Manufacturing (JCM 2016), 14-16 September, 2016, Catania, Italy. Springer: International Publishing pp. $156-166$

Beil Benjamin (20I0). First Person Perspectives: Point of View und figurenzentrierte Erzählformen im Film und im Computerspiel. Münster: Medien'welten LIT.

Bergamin Kevin, Clavet Simon, Holden Daniel, Forbes James Richard (2019). DReCon: data-driven responsive control of physics-based characters. In ACM Trans. Graph, 38, 6, Art. 206, pp. I - I I. 
Berger Laurenz, Wolf Katrin (2018). WIM: Fast Locomotion in Virtual Reality with Spatial Orientation Gain \& without Motion Sickness. In MUM 2018. Proceedings of the 17th International Conference on Mobile and Ubiquitous Multimedia, (MUM 20 18). Association for Computing Machinery, November 2018 , New York, NY, USA, pp. 19-24.

Bergström Ilias, Kilteni Konstantina, SlaterMel (20 I6). First-Person Perspective Virtual Body Posture Influences Stress: A Virtual Reality Body Ownership Study. In PloS one, II, 2, 2016, pp. I-2I.

Chardonnet Jean-Rémy, Mirzaei Mohammad Ali, Mérienne Frédéric (2017). Features of the Postural Sway Signal as Indicators to Estimate and Predict Visually Induced Motion Sickness in Virtual Reality. In International Journal of Human-Computer Interaction, 33: 10, 2017, pp. 77|-785

Chattha Umer Asghar, Shah Munam Ali (2018). Survey on Causes of Motion Sickness in Virtual Reality. In 24th International Conference on Automation and Computing (ICAC). Newcastle upon Tyne, United Kingdom. Newcastel: University press, pp. I-5.

Ding Mandy (2017). Augmented Reality in Museums. In Arts Management \& Technology Laboratory. Arts Management \& Technology Laboratory della Carnegie Mellon University, Heinz College pp. I - 12.

Gorisse Geoffrey, Christmann Olivier, Amato Etienne Armand et al. (2017). First- and Third-Person Perspectives in Immersive Virtual Environments: Presence and Performance Analysis of Embodied Users. In Frontiers in Robotics and Al, 4, p. 33.

Kullmann Karl (2014). Hyper-realism and loose-reality: the limitations of digital realism and alternative principles in landscape design visualization. In Journal of Landscape Architecture, 9:3, pp. 20-31.

Nielsen Lasse T., Møller Matias B., Hartmeyer Sune D. et al. (2016). Missing the point: an exploration of how to guide users' attention during cinematic virtual reality. In Proceedings of the 22nd ACM Conference on Virtual Reality Software and Technology (VRST 'I 6). New York: Association for Computing Machinery, pp. 229-232.

Nirkin Yuval, Keller Yosi, HassnerTal (2019). FSGAN: Subject Agnostic Face Swapping and Reenactment. In The IEEE International Conference on Computer Vision (ICCV), 29 Oct.-0I Nov. 20 19, Seoul, Korea, pp. 7I84-7I93.

Overby Alexandra, Jones Brian L. (20I5). Virtual LEGOs: Incorporating Minecraft into the Art Education Curriculum. In Art Education, 68: I, pp. $21-27$.

Pohl Brian J., Harris Andrew, Balog Michael et al. (2017). Fortnite: Supercharging 3D Animation Pipelines with Game Engine Technologies. In Digi Pro, 7, 2017, pp. I-4.

Sun Qi, Patnev Anjul, Wei Li-Yi, Saphira Omer et al. (2018). Towards Virtual Reality Infinite Walking: Dynamic Saccadic Redirection. In ACM Trans. Graph., 37, 4, 67, pp. I - 3.

Simolyanskiy Nikolai, Gonzales-Franco Mar (20 I7). Stereoscopic First Person View System for Drone Navigation. In Frontiers in Robotics and Al, 4, pp. I-I I.

Salamin Patrick, Tadi Tej, Blanke Olaf,Vexo Frederic, Thalmann Daniel (20I0). Quantifying Effects of Exposure to the Third and First-Person Perspectives in Virtual-Reality-Based Training. In IEEE Transactions on Learning Technologies, vol. 3, n. 3, pp. $272-276$.

Tevisan Elena (20 I5). II san Giovanni Evangelista di Jean François Niceron: la scoperta di un'apocalisse dell'Ottica. In Graziano Mario Valenti. Prospettive Architettoniche, pp. 365-374. Roma: Sapienza Edizioni.

\footnotetext{
Authors

Graziano Mario Valenti, Sapienza Università di Roma, grazianomario.valenti@uniromal.it Alessandro Martinelli, Sapienza Università di Roma, alessandro.martinelli@uniroma l.it
}

To cite this chapter.Valenti Mario Graziano, Martinelli Alessandro (2020). La 'vista in prima persona' tra esperienza reale e fruizione digitale/The 'first-person view' between real experience and digital use. In Arena A., Arena M., Brandolino R.G., Colistra D., Ginex G., Mediati D., Nucifora S Raffa P. (a cura di). Connettere. Un disegno per annodare e tessere. Atti del $42^{\circ}$ Convegno Internazionale dei Docenti delle Discipline della Rappresentazione/Connecting. Drawing for weaving relationships. Proceedings of the 42th International Conference of Representation Disciplines Teachers. Milano: FrancoAngeli, pp. 38||-3826. 